\title{
Genetic Characterization and Diversity of Rathayibacter toxicus
}

\author{
I. V. Agarkova, A. K. Vidaver, E. N. Postnikova, I. T. Riley, and N. W. Schaad
}

First, second, and third authors: Department of Plant Pathology, University of Nebraska, Lincoln; fourth author: Plant and Pest Science, University of Adelaide, Adelaide, SA, Australia; and fifth author: U.S. Department of Agriculture-Agricultural Research Service, Foreign Disease-Weed Science Research Unit, Ft. Detrick, MD.

Accepted for publication 21 June 2006.

\begin{abstract}
Agarkova, I. V., Vidaver, A. K., Postnikova, E. N., Riley, I. T., and Schaad, N. W. 2006. Genetic characterization and diversity of Rathayibacter toxicus. Phytopathology 96:1270-1277.

Rathayibacter toxicus is a nematode-vectored gram-positive bacterium responsible for a gumming disease of grasses and production of a highly potent animal and human toxin that is often fatal to livestock and has a history of occurring in unexpected circumstances. DNA of 22 strains of $R$. toxicus from Australia were characterized using amplified fragment length polymorphism (AFLP) and pulsed-field gel electrophoresis (PFGE).

AFLP analysis grouped the 22 strains into three genetic clusters that correspond to their geographic origin. The mean similarity between the three clusters was 85 to $86 \%$. PFGE analysis generated three different banding patterns that enabled typing the strains into three genotypic groups corresponding to the same AFLP clusters. The similarity coefficient was 63 to $81 \%$ for $\mathrm{Xba \textrm {I }}$ and 79 to $84 \%$ for SpeI. AFLP and PFGE analyses exhibited an analogous level of discriminatory power and produced congruent results. PFGE analysis indicated that the $R$. toxicus genome was represented by a single linear chromosome, estimated to be 2.214 to 2.301 Mb. No plasmids were detected.
\end{abstract}

The bacterium Rathayibacter toxicus $(41,44)$ is responsible for a gumming disease and ryegrass toxicity $(10,32,41)$ resulting in an often fatal poisoning of livestock in Australia (26). Although ryegrass toxicity has been reported in South Africa (46), no cultures of $R$. toxicus originating outside Australia are available. It is likely that contaminated Lolium rigidum L. (annual ryegrass) seed imported from Australia was responsible for this possible introduction. Rathayibacter spp. have been identified in orchard grass (Dactylis glomerata L.) seed in Oregon (1) and several reports have suggested the presence of $R$. toxicus in chewing's fescue (Festuca nigrescens Lam.) seed in Oregon $(26,37)$.

$R$. toxicus cells are gram-positive rods of coryneform morphology, and have a B2 $\gamma$ type cell wall peptidoglycan with 2,4diaminobutyric acid, predominant menaquinones of the MK-10 type, phosphatidyglycerol and diphosphatidyglycerol as basic polar lipids, and a high $\mathrm{G}+\mathrm{C}$ content of $67 \mathrm{~mol} \%(41,44)$. Several species of Anguina (seed and leaf gall nematodes) are known to carry $R$. toxicus into the host plant, where it colonizes the inflorescence or the galls formed by the nematode $(30,33,34,37-$ 40). Glycolipid toxins, known as corynetoxins, are produced by the bacterium as the grass matures and becomes senescent (15). Toxin production is considered to be regulated by a bacteriophage that is associated with the bacterium $(28,36)$. Animals that consume infected plants suffer a toxicosis characterized by episodic neurological symptoms, often leading to death $(5,18)$. In Australia, more than 100,000 sheep and thousands of cattle die from this disease in some years (14). In Australia, R. toxicus most commonly is found in L. rigidum with Anguina funesta as a vector (30), and Polypogon monspeliensis (rabbit-foot grass, called

Corresponding author: N. W. Schaad; E-mail address: norman.schaad@ars.usda.gov

DOI: $10.1094 /$ PHYTO-96-1270

This article is in the public domain and not copyrightable. It may be freely reprinted with customary crediting of the source. The American Phytopathological Society, 2006. annual beardgrass in Australia) and Lachnagrostis filiformis (syn. Agrostis avenacea, annual blowngrass) with an undescribed Anguina vector $(6,15,16,27)$. Gumming disease symptoms occasionally occur in other grasses, which are not hosts of any known nematode vector. In ryegrass swards infested with Anguina funesta, it is assumed that the nematode may invade and introduce $R$. toxicus into other plants at a low frequency, which further indicates that the bacterium is not host specific and may be latent in some hosts $(10,34,35)$. Novel host-vector combinations for $R$. toxicus, namely Triticum aestivum (wheat) with A. tritici (33) and Ehrharta longiflora (annual veldt grass) with A. australis (43), have been demonstrated experimentally. Apparently, R. toxicus is not vector specific to a particular species of Anguina (38) and $R$. toxicus potentially can colonize and produce toxin in a wide range of cereals and fodder grasses, including species consumed by humans (10). This makes $R$. toxicus a high-threatrisk foreign pathogen (14).

Little is known about genetic diversity of the organism. Typing of $R$. toxicus strains using serology and bacteriophage sensitivity have shown little variation among strains, and allozyme electrophoresis produced incomplete data $(21,32,36)$. Molecular techniques are considered the most accurate means of fingerprinting microorganisms on a species and subspecies level. Amplified fragment length polymorphism (AFLP) is one of the most powerful discriminatory fingerprinting techniques that employs selective amplification of restriction fragments from a digest of total genomic DNA (48). The technique has been used to characterize and fingerprint a broad range of plant pathogenic bacteria. $(11,19,31)$. Pulsed-field gel electrophoresis (PFGE) has been used for typing a number of phytopathogenic bacteria $(8,9,12,17)$. This sensitive fingerprinting technique is based on DNA macro restriction fragment variation obtained from the whole bacterial genome after digestion with a "rare cutting" endonuclease, followed by electrophoresis in a pulsed field (25).

Our objective was to determine the genetic diversity among strains of $R$. toxicus and examine their relationship to the geographic origin of strains, host plant and year of isolation. 


\section{MATERIALS AND METHODS}

Source of strains, growth, and extraction of DNA. The 22 strains of $R$. toxicus investigated (Table 1) were maintained by monthly transfer on nutrient broth yeast extract (NBY) agar (47). For DNA extraction, the bacteria were grown on a rotary shaker in Luria-Bertani broth (24). Genomic DNA was isolated by the modified Marmur method, as described $(20,45)$. Concentrations of DNA were determined with a spectrophotometer, standardized to $100 \mathrm{ng} / \mu \mathrm{l}$, and stored at $-20^{\circ} \mathrm{C}$.

AFLP. To obtain evenly distributed bands in the size range of 50 to $700 \mathrm{kbp}$, several combinations of "long cutters" (ApaI, EcoRI, and HindIII) and "short cutters" (HpaII, HpyCH4IV, MseI, and TaqI) were tested.

Several of the strains received from different collections had an identical origin (Table 1). These strains were included as a reproducibility control. Template DNA preparation for selective amplification was carried out according to Vos et al. (48) with slight modifications. Briefly, genomic DNA (100 ng) of each strain was digested with a combination of restriction endonucleases, and corresponding adaptors were ligated to the resulting restriction fragments. For selective amplification, $1 \mu \mathrm{l}$ of a 10 -fold-diluted ligation mixture was amplified with EcoRI+0 (5'-GAC TGC GTA CCA ATT C) and HpaII+A (5'-CGA TGA GTC CTC ACC GGA) primers in a GeneAmp PCR System 2700 (Applied Biosystems). EcoRI+0 primer was labeled with infrared fluorescent dye IRDye 700 (Li-Cor Inc, Lincoln, NE). Electrophoresis of the amplified products was performed on a $6.5 \%$ polyacrylamide gel using a LiCor Long ReadIR DNA Sequencer (model 4200). Image data were collected automatically and simultaneously recorded in a digital format during electrophoresis. The reproducibility of AFLP analysis was evaluated by comparing the fingerprints derived from control (duplicate) strains.

PFGE. Cultures were grown overnight in NBY broth, harvested, and embedded in $1 \%$ low-melting-point agarose. The agarose plugs were transferred into lysis solution $(10 \mathrm{mM}$ Tris, $\mathrm{pH}$ 8.0; 250 mM EDTA, pH 8.0; $1 \mathrm{M} \mathrm{NaCl} ; 0.2 \%$ sodium deoxycholate; and $0.5 \% \mathrm{~N}$-lauroylsarcosine) supplemented with lysozyme at $1 \mathrm{mg} / \mathrm{ml}$ and incubated at $37^{\circ} \mathrm{C}$ for $24 \mathrm{~h}$. After decanting the lysis solution, plugs were rinsed twice with cold ESP buffer
(250 mM EDTA, pH 9.5, and 1.0\% $N$-lauroylsarcosine). Then, the agarose blocks were treated for $48 \mathrm{~h}$ at $53^{\circ} \mathrm{C}$ with $2 \mathrm{ml}$ of ESP buffer containing proteinase $\mathrm{K}$ at $1 \mathrm{mg} / \mathrm{ml}$. The plugs were stored at $4{ }^{\circ} \mathrm{C}$ in ESP buffer. For digestion with restriction enzymes, the agarose blocks were washed four times (every wash at least 30 min) with $2 \mathrm{ml}$ of Tris-EDTA buffer, and restriction reactions with endonucleases were performed according to the manufacturer's instructions (New England Biolabs, Beverly, MA). After incubation overnight at $37^{\circ} \mathrm{C}$, the reaction was stopped with ESP buffer.

The DNA fragments were separated in a CHEF-DR II unit (Bio-Rad, Hercules, CA) in a $1 \%$ agarose gel. Electrophoresis conditions and running buffer were selected to resolve target DNA fragment size ranges (7).

The exact conditions used are described in the gel legends. The size of the $R$. toxicus genome was determined from the total value of all the PacI-generated fragments. The chromosomes of Hansenula wingei (1.05 to $3.13 \mathrm{Mb}$ ) (Bio-Rad), yeast chromosome PFG Marker (225 to 1,900 kbp), and low-range PFG marker (2.03 to $194 \mathrm{kbp}$ ) (New England Biolabs) were used as molecular weight markers. Gels were stained with ethidium bromide at $0.5 \mathrm{mg} /$ liter for $30 \mathrm{~min}$, destained in water for $2 \mathrm{~h}$, and then digital images were made with the ChemiDoc EQ System (Bio$\mathrm{Rad})$. To assess reproducibility of PFGE, at least three DNA preparations and gel runs for each strain were performed independently.

Data analysis. Quantity One software (Bio-Rad) was used for band analysis (fragment size and band intensity). A binary data set was generated for each strain based on absence or presence of bands. Analyses of phylogenetic relationships were done with Phylogenetic Analysis Using Parsimony (PAUP), version 4 (Sinauer Associates, Sunderland, MA), and the dendograms were constructed using the unweighted pair group method with averages (UPGMA).

\section{RESULTS}

AFLP. The EcoRI/HpaII combination with a set of amplification primers with one selective nucleotide EcoRI+0/HpaII+A produced the most suitable banding patterns. Up to 55 to 65

TABLE 1. Origin of strains of Rathayibacter toxicus used in this study and their amplified fragment length polymorphism (AFLP) group

\begin{tabular}{|c|c|c|c|c|}
\hline Group, laboratory no. ${ }^{\mathrm{y}}$ & Received as ${ }^{\mathrm{z}}$ & Original source & Host & Location and year isolated \\
\hline \multicolumn{5}{|l|}{ A } \\
\hline FH-138 & CS28 (ICMP 6307) & I. Riley & Lolium rigidum & Western Australia, 1978 \\
\hline FH-81 & CRK73dy dark & A. Payne & L. rigidum & Western Australia, 1973 \\
\hline FH-82 & CRK73dy light & A. Payne & L. rigidum & Western Australia, 1973 \\
\hline FH-86 & CRW1 dark & A. Payne & L. rigidum & Western Australia, 1974 \\
\hline FH-87 & CRW1 light & A. Payne & L. rigidum & Western Australia, 1974 \\
\hline FH-88 & CRW3 & A. Payne & L. rigidum & Western Australia, 1980 \\
\hline FH-89 & CRW3-160 & A. Payne & L. rigidum & Western Australia, 1980 \\
\hline FH-128 & Freshly isolated from galls & I. Riley & L. rigidum & Western Australia, 2001 \\
\hline FH-139 & $\mathrm{CS} 31$ & D. Chatel & Phalaris sp. & Western Australia, 1981 \\
\hline FH-140 & $\mathrm{CS} 3$ & I. Riley & L. rigidum & Western Australia, 1983 \\
\hline FH-142 & CS32 & D. Chatel & Austrodanthonia caespitosa & Western Australia, 1981 \\
\hline FH-144 & CS29 & D. Chatel & L. rigidum & Western Australia, 1981 \\
\hline FH-145 & CS30 & D. Chatel & Avena sativa & Western Australia, 1980 \\
\hline FH-146 & CS100 & I. Riley & A. caespitosa & Western Australia, 1991 \\
\hline \multicolumn{5}{|r|}{ 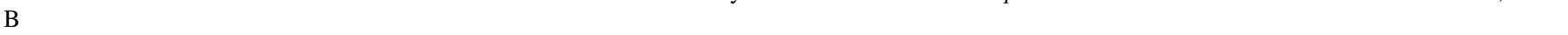 } \\
\hline FH-137 & CS14 (ICMP 9525) & ATCC 49908 & L. rigidum & South Australia, 1983 \\
\hline FH-83 & CRS2 dark & A. Payne & L. rigidum & South Australia, 1975 \\
\hline FH-85 & CRS3 & A. Payne & L rigidum & South Australia, 1975 \\
\hline FH-84 & CRS2 light & A. Payne & L. rigidum & South Australia, 1975 \\
\hline FH-141 & $\mathrm{CS} 2$ & A. F. Bird & L. rigidum & South Australia, 1983 \\
\hline FH-147 & CS33 & I. Riley & L. rigidum & South Australia, 1984 \\
\hline FH-183 & CS34 (ICMP 8527) & I. Riley & L. rigidum & South Australia, 1984 \\
\hline \multicolumn{5}{|r|}{ 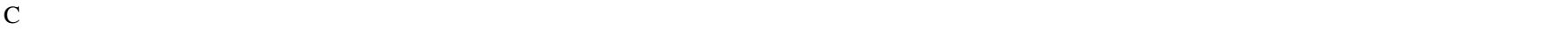 } \\
\hline FH-100 & SE3 & K. Ophel-Keller & Polypogon monspeliensis & South Australia, 1991 \\
\hline
\end{tabular}

y AFLP grouping based upon EcoRI+0/HpaII+A analysis.

z ICMP = International Collection of Micro-organisms from Plants. Auckland, New Zealand. 
evenly distributed bands were recorded, and 16 of them were polymorphic. The duplicate strains of $R$. toxicus produced highly homologous AFLP patterns and exhibited more than 95\% homology (data not shown). Only slight variation in band intensity was observed.

Cluster analysis (Fig. 1; Table 2) assigned the 22 R. toxicus strains into three AFLP clusters, A, B, and C, with a linkage of 84.7 to $90.1 \%$. The similarity coefficient for strains belonging to the same cluster varied from 2.9 to $5.2 \%$. There was a distinct pattern of strain grouping according to their geographical origin. Cluster A included 14 strains, all from Western Australia and associated with A. funesta: FH-81, FH-82, FH-86, FH-87, FH-88, FH-89, FH-128, FH-138, FH-139, FH-140, FH-142, FH-144, FH145, and FH-146. South Australian strains formed two clusters: cluster B contained seven strains all associated with A. funesta: FH-83, FH-84, FH-85, FH-137, FH-141, FH-147, and FH-183; and cluster $\mathrm{C}$ consisted of a single strain, FH-100, associated with Anguina spp. in P. monspelienesis from a geographically separate part of Australia.
PFGE. Genomic DNA isolated and purified in situ was digested with a number of restriction endonucleases. The choice of restriction enzyme for PFGE analysis was influenced by the high $\mathrm{G}+\mathrm{C}$ content of $R$. toxicus (67 mol\%) (44). Seven restriction endonucleases with A+T-rich recognition sites, such as 6-bp "cutters" AseI (AT/TAAT), DraI (TTT/AAA), EcoRI (G/AATTC), SpeI (A/CTAGT), SspI (AAT/ATT), and XbaI (T/CTAGA), and 8-bp cutter PacI (TTAAT/TAA), were tested.

Ase I produced an extensive number of bands in the size range from 15 to $200 \mathrm{kbp}$. EcoRI and $S s p$ I generated too many fragments, all of them under 20 and $70 \mathrm{kbp}$, respectively. Digestion with $\operatorname{DraI}$ resulted in 18 to 20 evenly distributed bands in a size range of 23 to $580 \mathrm{kbp}$. PacI digestion resulted in 4 to 5 bands in a size range of 251 to $798 \mathrm{kbp}$ (Fig. 2). SpeI and XbaI endonucleases produced the most suitable banding patterns for reliable PFGE analysis (Figs. 3 and 4).

PFGE exhibited a very high level of reproducibility; no variation between preparations of DNA or between runs was observed. Some bands were more intense or thicker, indicating closeness in
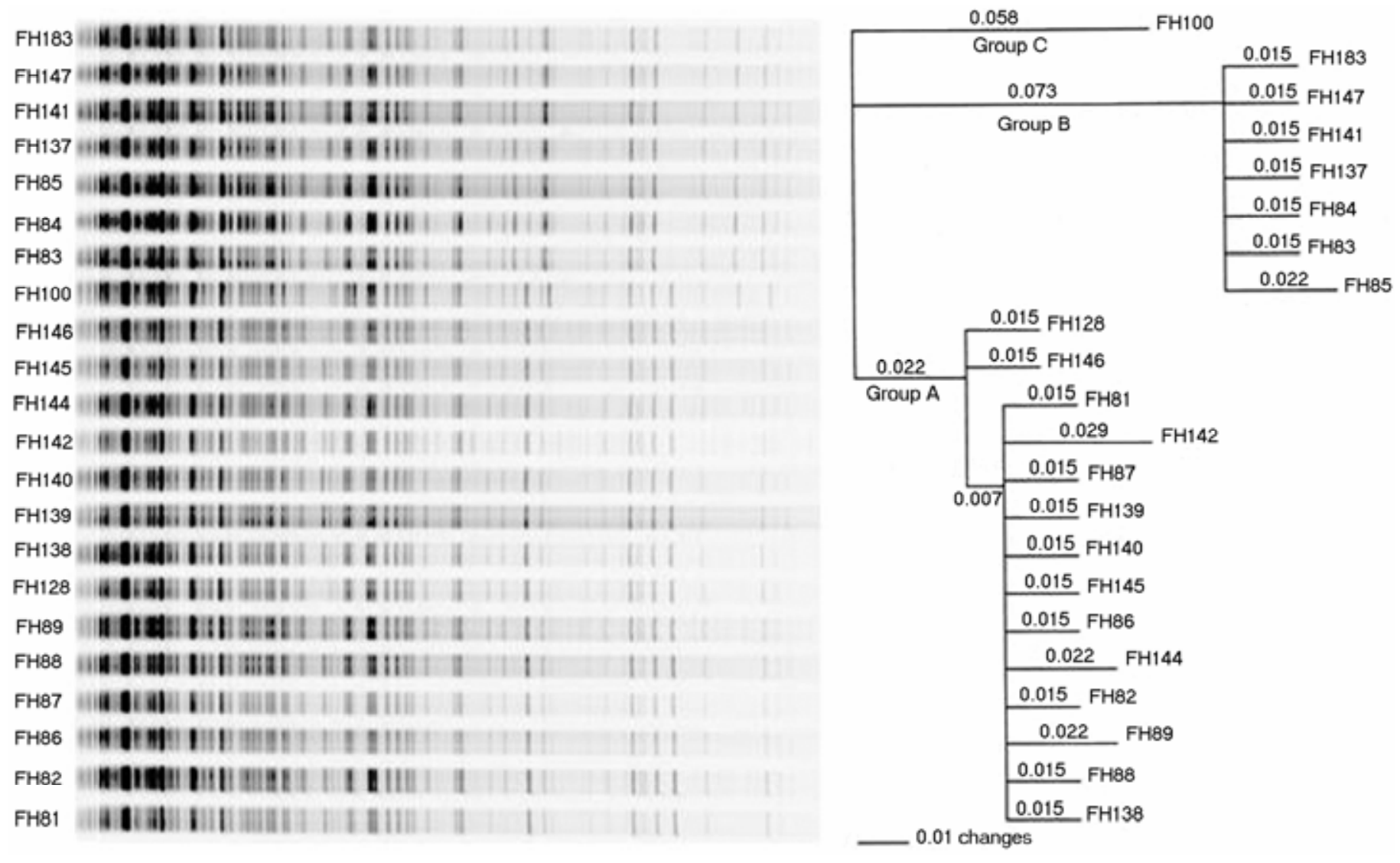

Fig. 1. Amplified fragment length polymorphism patterns based on EcoRI/MseI digestion and phylogenetic tree of 22 strains of Rathayibacter toxicus. Analysis of phylogenetic relationships was done with Phylogenetic Analysis Using Parsimony (PAUP), version 4 (Sinauer Associates, Sunderland, MA). The dendrogram was constructed using the unweighted pair group method with averages. The bar indicates $1 \%$ divergence and branch length shows dissimilarity between strains.

TABLE 2. Similarity percent for pairwise comparison of genomic fingerprints of Rathayibacter toxicus strains

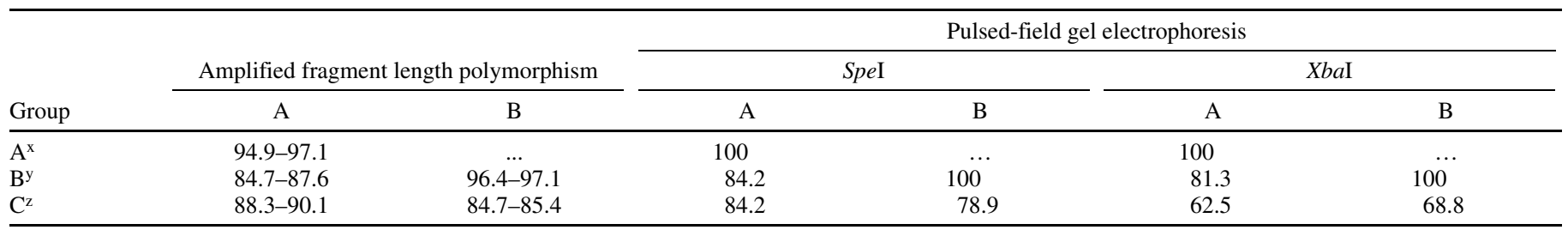

${ }^{\mathrm{x}}$ Group of Western Australian strains: FH-81, FH-82, FH-86, FH-87, FH-88, FH-89, FH-128, FH-138, FH-139, FH-140, FH-142, FH-144, FH-145, and FH-146; all with Anguina funesta as a vector.

${ }^{y}$ Group of South Australian strains: FH-83, FH-84, FH-85, FH-137, FH-141, FH-147, and FH-183, all with A. funesta as a vector.

${ }^{\mathrm{z}}$ Single strain (FH-100) from southeastern South Australia; vectored by Anguina spp. in the genus Polypogon. 


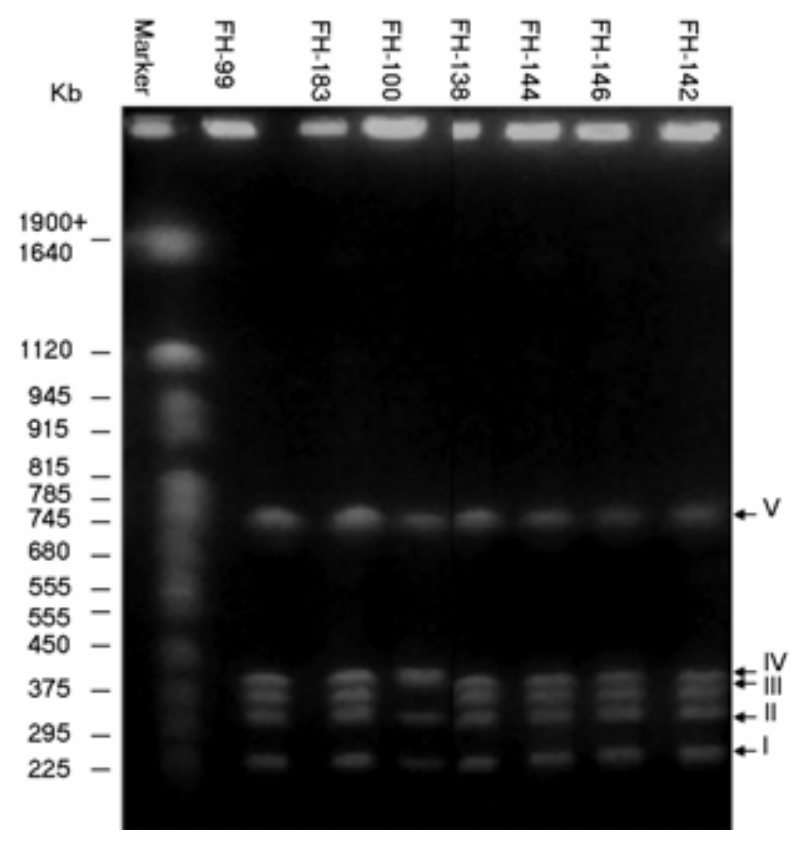

Fig. 2. Pulse-field gel electrophoresis pattern of PacI-digested Rathayibacter toxicus strains. Electrophoresis conditions were $0.5 \times$ Tris-borate EDTA buffer, $200 \mathrm{~V}$ for $26 \mathrm{~h}$, pulse time $70 \mathrm{~s}$ for $15 \mathrm{~h}$, and then $120 \mathrm{~s}$ for $11 \mathrm{~h}$. Marker was yeast chromosomes (New England Biolabs, Beverly, MA). The ladder size is shown on the left and the fragment designation is on the right. size of bands that comigrate. For adequate resolution of all macrorestriction fragments, several gel runs with different pulse times were applied. The resultant separation of almost all of the restricted fragments did not increase the discrimination power of PFGE analysis. Therefore, we chose to use a single run with one pulse time change in the middle of the run. Fragments restricted with $\mathrm{XbaI}$ endonuclease produced 12 to 13 DNA fragments, depending upon the strain, with the majority of bands in the size range of 40 to $240 \mathrm{kbp}$ (Fig. 3).

Digestion with SpeI generated 13 to 15 fragments in the range of 15 to $130 \mathrm{kbp}$ (Fig. 4). Both enzymes enabled differentiating strains into three analogous haplotypes, similar to those observed by AFLP with similarity coefficients in the range of 78.9 to $84.2 \%$ for SpeI digests and 62.5 to $81.3 \%$ for $\mathrm{XbaI}$ (Table 2).

Genome organization and topology. Digestion of $R$. toxicus DNA from different geographical groups with $\mathrm{PacI}$ endonucleases resulted in five fragments (I, II, III, IV, and V) in a size range of 251 to $798 \mathrm{kbp}$ (Fig. 2; Table 3). The genome size of $R$. toxicus was estimated at 2.214 to $2.301 \mathrm{Mb}$.

Strain FH-100 exhibited four fragments in the same size range. The intensity of fragment III (448 kbp) was much stronger than that of fragments I (259 kbp) and II (351 kbp), indicating comigration of two fragments that are very close in size. Analysis of band intensity with Quantity One (Bio-Rad) software showed the relative quantity (intensity expressed as percentage of the total intensity of all the bands in the lane) for fragment I at $19.3 \%$, fragment II at $12.2 \%$, fragment III at 40.2 , and fragment IV at

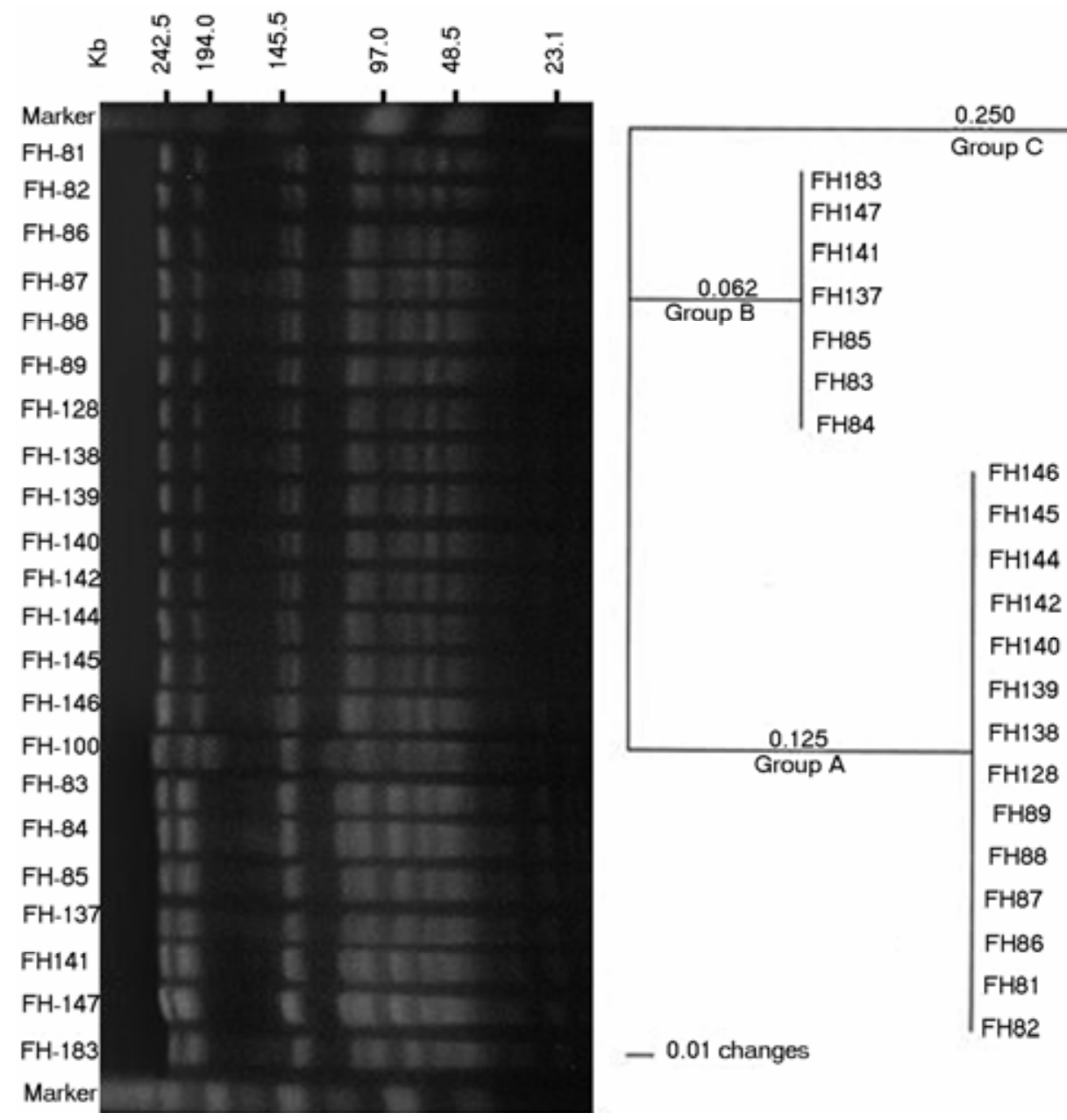

Fig. 3. Pulse-field gel electrophoresis (PFGE) patterns and phylogenetic tree of 22 strains of Rathayibacter toxicus digested with XbaI. Analysis of phylogenetic relationships was done with Phylogenetic Analysis Using Parsimony (PAUP), version 4 (Sinauer Associates, Sunderland, MA). The dendrogram was constructed using the unweighted pair group method with averages. The bar indicates $1 \%$ divergence and branch length shows dissimilarity between strains. The electrophoresis conditions consisted of the following: 0.5x Tris-borate EDTA buffer, $200 \mathrm{~V}$ with ramped pulses of 3 to $30 \mathrm{~s}$ for $8 \mathrm{~h}$ and of 1 to $13 \mathrm{~s}$ for $12 \mathrm{~h}$. Marker: Low Range PFG Marker (New England Biolabs, Beverly, MA). 
$28.4 \%$, thus confirming our prediction for the presence of two similar size fragments (448 kbp).

To avoid underestimation of the genome size and to demonstrate that $\mathrm{PacI}$ restriction nucleases digested all genetic elements present in the $R$. toxicus genome, $R$. toxicus DNA (embedded into agarose blocks) was retrieved from the agarose gel wells, digested with EcoRI nucleases, and subjected to a second electrophoresis. No DNA fragments were detected, thus verifying that all genetic elements present in the $R$. toxicus genome were digested and resolved by $P a c$ I analysis.

To investigate the presence of any extrachromosomal replicons in the $R$. toxicus strains, intact genome DNA in agarose blocks was subjected to PFGE for $60 \mathrm{~h}$ at $100 \mathrm{~V}$ with the pulse time ramped from 250 to $900 \mathrm{~s}$. Results showed the megasized genomic DNA entered the gel and migrated as a distinct fragment size of $2.35 \mathrm{Mb}$ (Fig. 5). To determine whether this band migrated as a linear chromosome in a pulse-time-dependent manner, the pulse conditions were changed to affect migration of only circular but not linear elements. The results showed the megasize fragment migrated as a linear DNA at a rate comparable with linear DNA ladders and consistently exhibited a size of $2.35 \mathrm{Mb}$.

To linearize any cryptic supercoiled circular elements possibly present in the $R$. toxicus genome, $\mathrm{S} 1$ nuclease treatment of genomic DNA in agarose plugs was performed (4). S1 nuclease digestion of $R$. toxicus DNA did not produce any additional bands and did not change the migration rate of the $2.35-\mathrm{Mb}$ band of any strain.

\section{DISCUSSION}

The 22 Australian strains of $R$. toxicus were successfully fingerprinted using two DNA-based methods: AFLP and PFGE.

AFLP analysis (48) has proven to work well for fingerprinting bacteria at the strain level. It has been shown that 10 to 20 polymorphic bands are optimal for comparative analysis (22). The combination of enzymes and selective nucleotide extension of

TABLE 3. Size of PacI-digested fragments for three geographical groups (A, B, and C) of Rathayibacter toxicus

\begin{tabular}{lccc}
\hline & \multicolumn{3}{c}{ Size $(\mathrm{kbp})$} \\
\cline { 2 - 4 } DNA fragment & $\mathrm{A}(\mathrm{FH}-138)^{\mathrm{x}}$ & $\mathrm{B}(\mathrm{FH}-99)^{\mathrm{y}}$ & $\mathrm{C}(\mathrm{FH}-100)^{\mathrm{z}}$ \\
\hline I & 261 & 251 & 259 \\
II & 355 & 348 & 351 \\
III & 401 & 392 & 448 \\
IV & 432 & 429 & 448 \\
V & 798 & 794 & 795 \\
Totals & 2,247 & 2,214 & 2,301 \\
\hline
\end{tabular}

${ }^{x}$ Group of Western Australian strains, with Anguina funesta as a vector.

${ }^{y}$ Group of South Australian strains, with A. funesta as a vector.

${ }^{\mathrm{z}}$ A single strain, with Anguina spp. in genus Polypogon as a vector.

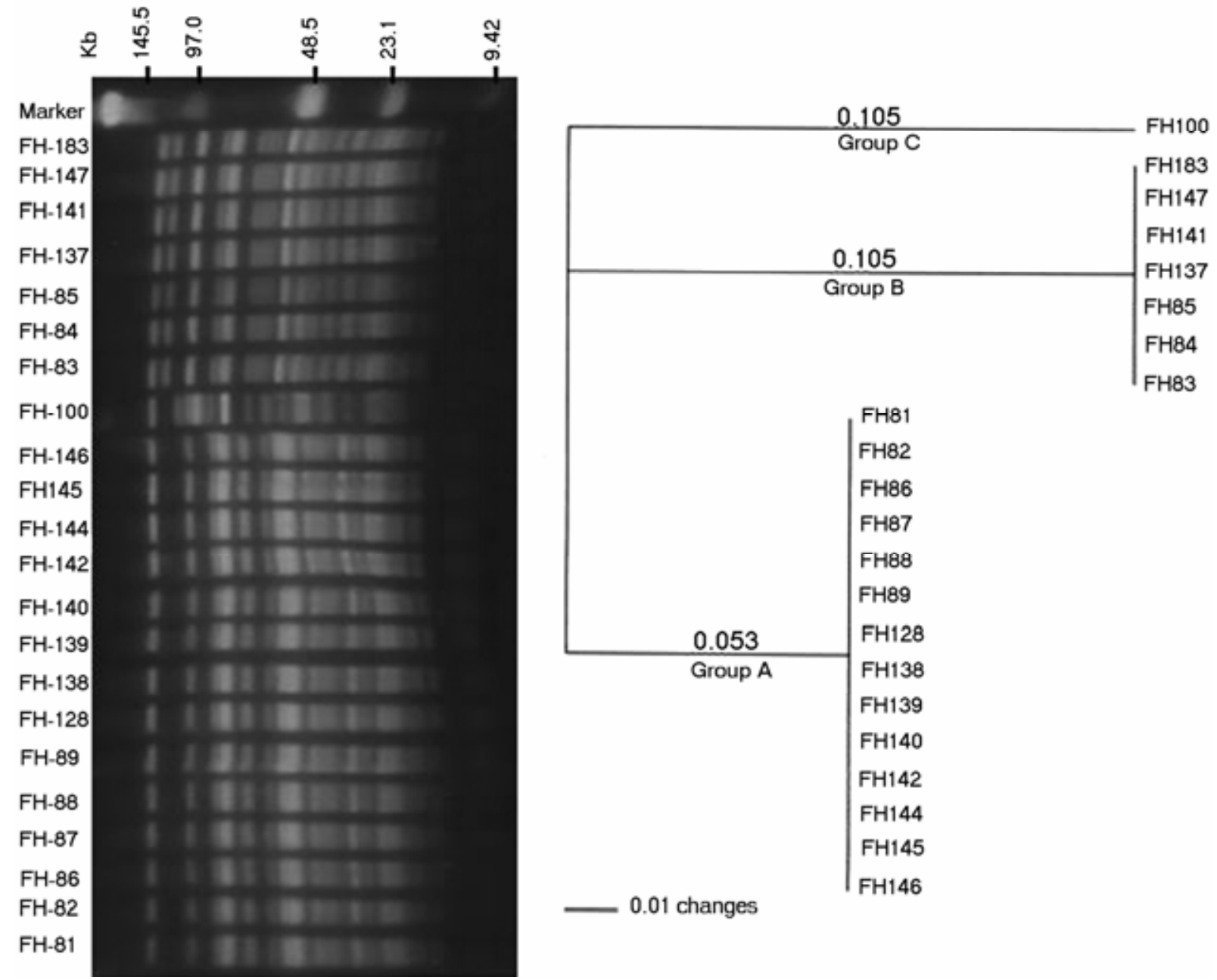

Fig. 4. Pulse-field gel electrophoresis (PFGE) patterns and phylogenetic tree of Rathayibacter toxicus digested with SpeI. Analysis of phylogenetic relationships was done with Phylogenetic Analysis Using Parsimony (PAUP), version 4 (Sinauer Associates, Sunderland, MA). The dendrogram was constructed using the unweighted pair group method with averages. The bar indicates $1 \%$ divergence and branch length shows dissimilarity between strains. The electrophoresis conditions consisted of the following: $0.5 \times$ Tris-borate EDTA buffer, $200 \mathrm{~V}$ with switch from 4 to $20 \mathrm{~s}$ for $4 \mathrm{~h}$ and from 1 to $10 \mathrm{~s}$ for $16 \mathrm{~h}$. Marker: Low Range PFG Marker (New England Biolabs, Beverly, MA). 
primers for AFLP analysis of $R$. toxicus were optimized; the EcoRI+0/HpaII+A primer combination produced a banding pattern suitable for fingerprinting of $R$. toxicus strains.

The results of these AFLP analyses were highly reproducible. The differences between control strains were less than 5\%. Minor variability recorded between duplicate strains could arise from slight fluctuation within different AFLP reactions or the amount of polymerase chain reaction product loaded into the gel wells. The data show that up to $5 \%$ of the differences can be disregarded.

PFGE has been shown to be an effective diagnostic tool widely applied in clinical microbiology for bacterial strain identification and differentiation, and for fingerprinting and tracing sources of pathogenic organisms (25).

Macrorestriction digestion followed by electrophoresis in a pulsed field has been shown to be a valuable tool for differentiation of species and pathovars of many plant-pathogenic bacteria, such as closely related gram-positive Clavibacter michiganensis subsp. sepedonicus (8), Curtobacterium flaccumfaciens (17), and Rhodococcus fascians (29).

PFGE analysis using SpeI and XbaI restriction endonucleases enabled typing of 22 Rathayibacter toxicus strains into three geographical groups and showed a level of sensitivity similar to AFLP. The coherence of PFGE results from at least three independent experiments shows that PFGE analysis is a highly reproducible method for typing $R$. toxicus strains.

Application of PacI restriction nuclease allowed digestion and resolution of the whole $R$. toxicus genome. A second digestion with EcoRI agarose plugs, recovered from gel wells after PacI analysis, did not indicate the presence of any DNA left undigested by PacI. The choice of EcoRI restriction endonuclease for a second digestion was influenced by the fact that this enzyme cuts $R$. toxicus DNA into fragments of less than $20 \mathrm{kbp}$, thus assuring that no DNA elements remained unresolved.

The very close similarity in the $R$. toxicus genome size obtained from intact DNA (2.35 Mb) and from PacI-digested DNA (2.214 to $2.301 \mathrm{Mb}$ ) corroborates the conclusion that all genetic elements present in the bacterium were resolved. The $2.35-\mathrm{Mb}$ replicon in $R$. toxicus appears to be linear and is the only chromosome.

The first linear bacterial chromosome was described in 1989 for Borrelia burgdorferi (3). Since then, linear chromosomes have been described for several Streptomyces spp. $(23,49)$ and the gram-positive bacterium Rhodococcus fascians strain D188 (13). However, the latter report was disproved by Pisabarro et al. (29). The genome of the gram-negative Agrobacterium tumefaciens C58 includes four replicons: two plasmids and two chromosomes, a circular one of $3.0 \mathrm{Mb}$ and a linear one of $2.1 \mathrm{Mb}$ (2). Thus, our description of a linear chromosome in $R$. toxicus is unusual but not unique for a bacterial genome.

The $R$. toxicus genome is 2.214 to $2.301 \mathrm{Mb}$. This is similar in size to the 2.50 to $2.64 \mathrm{Mb}$ for the related gram-positive plant pathogenic Clavibacter michiganensis subsp. sepedonicus (8).

A number of genotypic methods, including serology, multilocus enzyme electrophoresis (MEE), and phage typing have been investigated for typing $R$. toxicus strains $(21,32,36,42)$. The serological analysis and phage typing failed to reveal any differences among strains of $R$. toxicus. Population genetic analysis using MEE resulted in contradictory results. Johnson et al. (21) separated 52 strains of $R$. toxicus into 12 groups with a genetic distance of 0.06 to 0.23 ; there was no clear pattern of strain distribution with respect to evolutionary time, place, or host plant of origin. In contrast, Riley et al. (42), using allozyme electrophoresis, typed 11 strains of $R$. toxicus into three MEE clusters with a linkage of $82 \%$. The clusters corresponded very well with their geographical origin. Cluster A1 included strains CS1 (FH-188), CS2 (FH-141), CS14 (FH-79), and CS34 (FH-183) from South Australia; cluster A2 consisted of strain CS33 (FH-147) only; and cluster A3 included strains CS3 (FH-140), CS28 (FH-138), and
CS32 (FH-142) from Western Australia. Based on MEE and differences in the specificity of the adhesion of these strains to the cuticle of their nematode (Anguina spp.) vectors, Riley and McKay (38) proposed that there was a genetic divergence among the populations from these two geographically isolated regions.

Our results agree with the results of Riley et al. (42) except for results of strain CS33 (FH-147). They typed this strain into MEE cluster A2, whereas we found it typed with the majority of the other South Australian strains (group B) with a linkage of 96.4 to $97.1 \%$ by AFLP typing and $100 \%$ by PFGE typing.

We analyzed 22 representative strains of $R$. toxicus. The strains were isolated from a broad range of host plants of different geographical regions within Australia over a period of more than 30 years. The genome of $R$. toxicus seems to be highly conserved, with high similarity values for both AFLP (84.7 to 97.1\%) and PFGE (62.5 to $100 \%)$. The AFLP and PFGE data showed that the population of $R$. toxicus is very stable and has not undergone changes over many years. West Australian strains FH-81, FH-82, $\mathrm{FH}-86$, FH-87, and FH-138 isolated in the 1970s were indistinguishable from strain FH-128 isolated 31 years later in 2001. The population structure was not host plant specific. Strains isolated from L. rigidum (FH-81, FH-82, FH-86, FH-87, FH-88, FH89, FH-128, FH-138, FH-140, and FH-144) exhibited band patterns similar to strains isolated from Phalaris spp. (FH-139), Austrodanthonia caespitosa (FH-142, FH-146), and A. sativa (FH-145 and FH-146). In all cases, these infected plants were found among infected $L$. rigidum and represent incidental, nonspecific invasion by Anguina funesta of grasses in which it is unable to reproduce (40). Apparently, $R$. toxicus is not host specific and its infection of grass is determined largely by the specificity of its vector nematode.

Not only is there no evidence of genetic change over the period that the $R$. toxicus strains were collected, but the lack of genetic variation within the two geographical regions, separated by $1,800 \mathrm{~km}$, also suggests that these areas are not within the bacterium's center of origin. Given that L. rigidum is an exotic weed of cropping regions in Western and South Australia, it is likely that A. funesta also was introduced. The center of origin of the

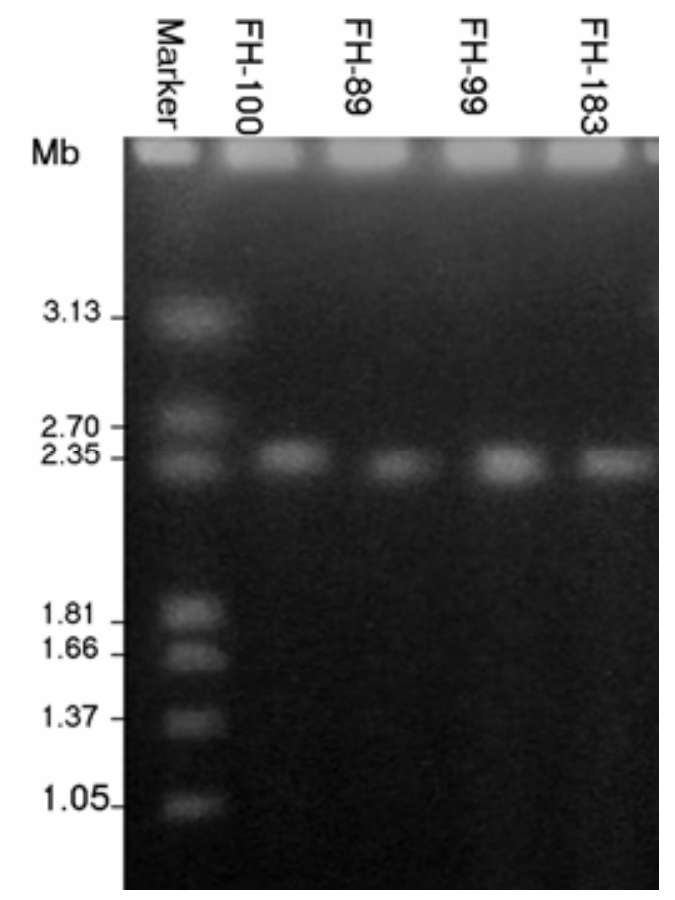

Fig. 5. Pulse-field gel electrophoresis of intact Rathayibacter toxicus DNA. Electrophoresis conditions were $1 \times$ Tris-acetate EDTA buffer, $100 \mathrm{~V}$ for $60 \mathrm{~h}$, pulse ramped from 250 to $900 \mathrm{~s}$. Marker was chromosomes of Hansenula wingei (Bio-Rad) with the ladder size shown on the left. 
bacterium is not known; however, the finding that $R$. toxicus from $P$. monspeliensis is distinct indicates a need for further characterization of strains associated with this vector in $P$. monspeliensis and Lachnagrostis filiformis. L. filiformis is an Australian native and its populations are geographically separated from the area of A. funesta infestation in Lolium rigidum; therefore, it could be the original source of the bacterium. However, the conjectured association of corynetoxins with a different nematode in $F$. nigrescens in the United States and New Zealand (37) suggests that the center of origin of $R$. toxicus may not have been Australia despite its common occurrence as an economic pest in that country.

Despite apparent differences between AFLP and PFGE analyses, the techniques generally have similar approaches to fragment generation. They both employ total genomic DNA and rely on the presence or absence of specific restriction sites along the whole bacterial genome. In both techniques, the number and size range of fragments can be adjusted by a choice of restriction enzymes. PFGE reveals all macro restriction fragments derived from the genome and enables one to obtain information about genome topology and complexity of organization. In contrast, AFLP does not provide any data on genome organization and generates only a subset of amplified fragments. However, AFLP is faster to perform, less laborious, does not require expensive equipment, and is more applicable for a large number of strains tested simultaneously.

Most molecular-based typing techniques employ restriction fragments derived from a gene or a single chromosome locus. An accidental recombination (rearrangement, insertions, deletions, or point mutation) might influence the genotypic results derived from a single locus. The advantage of AFLP and PFGE over such techniques is that multiple bands are derived from the entire genome, increasing their reliability.

The comparative analysis of data obtained with PFGE and AFLP showed that both methods produce congruent results, thus having similar levels of reliability. The only divergence between data produced by PFGE and AFLP analyses was a different linkage level among strains. The higher AFLP similarity coefficients compared with those obtained with PFGE most likely are due to the large number of generated fragments available for statistical analysis.

Results of AFLP and PFGE reveal the presence of three distinct haplotypes among the 22 strains of $R$. toxicus from Australia. These results show that AFLP and PFGE analyses are both robust and reproducible and provide a high level of discrimination among strains of $R$. toxicus.

\section{ACKNOWLEDGMENTS}

We thank A. Payne for kindly providing many of the strains used in this study and W. Schneider and P. Tooley for critically reading the manuscript.

\section{LITERATURE CITED}

1. Alderman, S. C., Bilsland, D. M., Griesback, J. A., Milbrath, G. M., Schaad, N. W., and Postnikova, E. 2003. Use of a novel seed scarifier for detection and enumeration of galls of Anguina and Rathayibacter species in orchard grass seed. Plant Dis. 87:320-323.

2. Allardet-Servent, A., Michaux-Charachon, S., Jumas-Bilak, E., Karayan, L., and Ramuz, M. 1993. Presence of one linear and one circular chromosome in the Agrobacterium tumefaciens C58 genome. J. Bacteriol. 175:7869-7874.

3. Baril, C., Richaud, C., Baranton, G., and Saint Girons, I. 1989. Linear chromosome of Borrelia burgdorferi. Res. Microbiol. 140:507-516.

4. Barton, B. M., Harding, G. P., and Zuccarelli, A. J. 1995. A general method for detecting and sizing large plasmids. Anal. Biochem. 226:235-240.

5. Berry, P. H., Howell, J. M., and Cook, R. D. 1980. Morphological changes in the central nervous system of sheep affected with experimental annual ryegrass (Lolium rigidum) toxicity. J. Comput. Pathol. 90:603-617.

6. Bertozzi, T., and McKay, A. C. 1995. Incidence on Polypogon monspeliensis of Clavibacter toxicus and Anguina sp., the organisms associated with "flood plain staggers" in South Australia. Aust. J. Exp. Agric. 35:567-569.

7. Birren, B., and Lai, E. 1993. Pulsed Field Gel Electrophoresis. A Practical Guide. Academic Press, New York.

8. Brown, S. E., Reilley, A. A., Knudson, D. L., and Ishimaru, C. A. 2002. Genomic fingerprinting of virulent and avirulent strains of Clavibacter michiganensis subspecies sepedonicus. Curr. Microbiol. 44:112-119.

9. Chan, J. W. Y. F., and Goodwin, P. H. 1999. Differentiation of Xanthomonas campestris pv. phaseoli from Xanthomonas campestris pv. phaseoli var. fuscans by PFGE and RFLP. Eur. J. Plant Pathol. 105:867878.

10. Chatel, D. L., Wise, J. L., and Marfleet, A. G. 1979. Ryegrass toxicity organism found on other grasses. J. Agric. West. Aust. (4th ser.) 20:89.

11. Clerc, A., Manceau, C., and Nesme, X. 1998. Comparison of randomly amplified polymorphic DNA with amplified fragment length polymorphism to assess genetic diversity and genetic relatedness within genospecies III of Pseudomonas syringae. Appl. Environ. Microbiol. 64:11801187.

12. Cooksey, D. A., and Graham, J. H. 1989. Genomic fingerprinting of two pathovars of phytopathogenic bacteria by rare cutting restriction enzymes and field inversion gel electrophoresis. Phytopathology 79:745-749.

13. Crespi, M., Messens, E., Caplan, A. B., van Montagu, M., and Desomer, J. 1992. Fasciation induction by the phytopathogen Rhodococcus fascians depends upon a linear plasmid encoding a cytokinin synthase gene. EMBO J. 11:795-804

14. Edgar, J. 2004. Future impact of food safety issues on animal production and trade: Implication for research. Aust. J. Exp. Agric. 44:1073-1078

15. Edgar, J. A., Cockrum, P. A., Stewart, P. L., Anderton, N. A., and Payne, A. L. 1994. Identification of corynetoxins as the cause of poisoning associated with annual beardgrass (Polypogon monspeliensis (L) Desf.) and blown grass (Agrostis avenacea $\mathrm{C}$. Gemelin). In: Plant Associated Toxins: Agricultural, Phytochemical and Ecological Aspects. S. M. Colegate and P. R. Dorling, eds. 4th Int. Symp. Poisonous Plants (ISOPP4), Fremantle, Western Australia, Australia. CAB International: Tucson, AZ.

16. Finnie, J. W. 1991. Corynetoxin poisoning in sheep in the southeast of South Australia associated with annual beard grass (Polypogon monspeliensis). Aust. Vet. J. 68:70.

17. Guimaraes, P. M., Smith, J. J., Palmano, S., and Saddler, G. S. 2003. Characterization of Curtobacterium flaccumfaciens pathovars by AFLP, rep-PCR and pulsed field-gel electrophoresis. Eur. J. Plant Pathol. 109:817-825.

18. Jago, M. V., and Culvenor, C. C. J. 1987. Tunicamycin and corynetoxin poisoning in sheep. Aust. Vet. J. 65:232-235.

19. Janssen, P., Coopman, R., Huys, G., Swings, J., Bleeker, M., Vos, P., Zabeau, M., and Kersters, K. 1996. Evaluation of the DNA fingerprinting method AFLP as a new tool for bacterial taxonomy. Microbiology 142:1881-1893.

20. Johnson, J. L. 1994. Similarity analysis of DNAs. Pages 665-682 in: Methods for General and Molecular Bacteriology. P. Gerhardt, R. G. E. Murray, W. A. Wood, and N. R. Krieg, eds. ASM, Washington, D.C.

21. Johnson, M. S., Sutherland, S. S., Constantine, C. C., and Hampson, D. J. 1996. Genetic analysis of Clavibacter toxicus, the agent of annual ryegrass toxicity. Epidemiol. Infect. 117:393-400.

22. Huys, G., Coopman, R., Janssen, P., and Kersters, K. 1996. High-resolution genotyping analysis of the genus Aeromonas by AFLP fingerprinting. Int. J. Syst. Bacteriol. 46:572-580.

23. Lezhava, A., Mizukami, T., Kajitani, T., Kameoka, D., Redenbach, M., Shinkawa, H., Nimi, O., and Kinashi, H. 1995. Physical map of the linear chromosome of Streptomyces griseus. J. Bacteriol. 177:6492-6498.

24. Luria, S. E., Adams, J. N., and Ting, R. C. 1960. Transduction of lactoseutilizing ability among strains of $E$. coli and $S$. dysenteriae and the properties of the transducing phage particles. Virology 12:348-390.

25. Maslow, J. N., Slutskey, A. M., and Arbeit, R. D. 1993. Molecular epidemiology: Application of contemporary techniques to the typing of microorganisms. Clin. Infect. Dis. 17:153-164.

26. McKay, A. C., and Ophel, K. M. 1993. Toxigenic Clavibacter/Anguina associations infecting grass seedheads. Annu. Rev. Phytopathol. 31:151167.

27. McKay, A. C., Ophel, K. M., Reardorn, T., and Gooden, J. 1993. Livestock deaths associated with Clavibacter toxicus/Anguina sp. Infection in seedheads of Agrostis avenacea and Polypogon monspeliensis. Plant Dis. 77:635-641.

28. Ophel, K., Bird, A., and Kerr, A. 1993. Association of bacteriophage particles with toxin production by Clavibacter toxicus, the causal agent of annual ryegrass toxicity. Phytopathology 83:676-681.

29. Pisabarro, A., Correia, A., and Martin, J. F. 1998. Pulsed field gel electrophoresis analysis of the genome of Rhodococcus fascians: Genome size and linear and circular replicon composition in virulent and avirulent strains. Curr. Microbiol. 36:302-308. 
30. Price, P. C., Fisher, J. M., and Kerr, A. 1979. On Anguina funesta n. sp. and its association with Corynebacterium sp. in infecting Lolium rigidum. Nematologica 25:76-85.

31. Restrepo, S., Duque, M., Tohmeand, J., and Verdier, V. 1999. AFLP fingerprinting: An efficient technique for detecting genetic variation of Xanthomonas axonopodis pv. manihotis. Microbiology 145:107114.

32. Riley, I. T. 1987. Serological relationships between strains of coryneform bacteria responsible for annual ryegrass toxicity and other plant-pathogenic corynebacteria. Int. J. Syst. Bacteriol. 35:153-159.

33. Riley, I. T. 1992. Anguina tritici is a potential vector of Clavibacter toxicus. Australas. Plant Pathol. 21:147-148.

34. Riley, I. T. 1995. Vulpia myuros and the annual ryegrass toxicity organisms, Anguina funesta, and Clavibacter toxicus. Fundam. Appl. Nematol. 18:595-598.

35. Riley, I. T. 1996. Dilophospora alopecuri on Lolium rigidum and Holus lanatus in southeastern Australia. Australas. Plant Pathol. 25:255-259.

36. Riley, I. T., and Gooden, J. M. 1991. Bacteriophage specific for the Clavibacter sp. associated with annual ryegrass toxicity. Lett. Appl. Microbiol. 12:158-160.

37. Riley, I. T., Gregory, A. R., Allen, J. G., and Edgar, J. A. 2003. Poisoning of livestock in Oregon in the 1940s to 1960s attributed to corynetoxins produced by Rathayibacter in nematode galls in chewing fescue (Festuca nigrescens). Vet. Hum. Toxicol. 45:160-162.

38. Riley, I. T., and McKay, A. C. 1990. Specificity of the adhesion of some plant pathogenic micro-organisms to the cuticle of nematodes in the genus Anguina (Nematoda: Anguinidae). Nematologica 36:90-103.

39. Riley, I. T., and McKay, A. C. 1991. Inoculation of Lolium rigidum with Clavibacter sp., the bacterium responsible for toxicity of annual ryegrass. J. Appl. Bacteriol. 71:302-306.
40. Riley, I. T., and McKay, A. C. 1991. Invasion of some grasses by Anguina funesta (Nematoda, Anguinidae) juveniles. Nematologica 37:447-454.

41. Riley, I. T., and Ophel, K. M. 1992. Clavibacter toxicus sp. nov., the toxigenic bacterium responsible for annual ryegrass toxicity in Australia. Int. J. Syst. Bacteriol. 42:92-96.

42. Riley, I. T., Reardon, T. B., and McKay, A. C. 1988. Genetic analysis of plant pathogenic bacteria in the genus Clavibacter using allozyme electrophoresis. J. Gen. Appl. Microbiol. 34:3025-3030.

43. Riley, I. T., Schmitz, A., and de Silva, P. 2001. Anguina australis, a vector for Rathayibacter toxicus in Ehrharta longiflora. Australas. Plant Pathol. 30:171-175.

44. Sasaki, J., Chijimatsu, M., and Suzuki, K. I. 1998. Taxonomic significance of 2,4-diaminobutyric acid isomers in the cell wall peptidoglycan of actinomycetes and reclassification of Clavibacter toxicus as Rathayibacter toxicus comb. nov. Int. J. Syst. Bacteriol. 48:403-410.

45. Schaad, N. W., Postnikova, E., Lacy, G., Fatmi, M., and Chang, C. J. 2004. Xylella fastidiosa subspecies: X. fastidiosa subsp. fastidiosa, subsp. nov., $X$. fastidiosa subsp. multiplex subsp. nov., and $X$. fastidiosa subsp. pauca subsp. nov. Syst. Appl. Microbiol. 27:290-300.

46. Schneider, D. J. 1981. First report of annual ryegrass toxicity in the Republic of South Africa. Onderstepoort J. Vet. Res. 48:251-255.

47. Vidaver, A. K. 1967. Synthetic and complex media for rapid detection of fluorescence of phytopathogenic pseudomonas: Effect of the carbon source. Appl. Microbiol. 15:1523-1524.

48. Vos, P., Hogers, R., Bleeker, M., Reijans, M., van de Lee, T., Hornes, M., Frijters, A., Pot, J., Peleman, J., Kuiper, M., and Zabeau, M. 1995. AFLP, a new technique for DNA fingerprinting. Nucleic Acids Res. 23:4407-4414.

49. Yi-Shing, L., Kieser, H. M., Hopwood, D. A., and Chen, C. W. 1993. The chromosomal DNA of Streptomyces lividans 66 is linear. Mol. Microbiol. 10:923-933. 